\title{
Transgenic mice as research tools in neurocarcinogenesis
}

\author{
Ugo Rovigatti $^{1}$, Tatiana Afanasyeva ${ }^{1}$, Sebastian Brandner ${ }^{1}$, Johannes A Hainfellner ${ }^{1}$, Markus Kiess ${ }^{1}$, \\ Alessia Maddalena ${ }^{1}$, Gerhard Malin ${ }^{1}$, Thomas Rülicke ${ }^{2}$, Joachim Steinbach ${ }^{1}$, Jakob Weissenberger ${ }^{1}$ \\ and Adriano Aguzzi ${ }^{1}$ \\ ${ }^{1}$ Institute of Neuropathology, Department of Pathology, Universitätsspital Zürich; ${ }^{2}$ Biologisches Zentrallabor, \\ Universitätsspital Zürich, Switzerland
}

\begin{abstract}
Transgenic animal models for neurocarcinogenesis have provided significant insights into the molecular mechanisms underlying carcinogenic processes, including those which affect the nervous system. In view of the very rapid pace of acquisition of knowledge, it is not possible to cover all transgenic mouse models for neural tumors. Instead, this article discusses some of the most important technical innovations for manipulation of the mammalian genome (notably the various methods for targeted genome modifications, as well as the technology for introducing large DNA fragments into the germ line of mice), and presents a selection of the transgenic mouse models which are proving most promising for furthering our understanding of the pathogenetic basis of cancer in the nervous system.
\end{abstract}

Keywords: transgenic mice; neurocarcinogenesis models; knock out mice

\section{The new tools of transgenesis}

Although transgenic mice continue to be highly complex systems (Hanahan, 1989), the last years have witnessed significant technical improvements in the field of transgenesis, and many long-standing problems can now be overcome. The conventional method of generation of transgenic mice by pronuclear microinjection leads to random integration of an undefined number of copies of the construct of interest. While fast and often very efficient, this approach is fraught with significant drawbacks, notably poor or unpredictable expression levels, and ectopic expression of the transgene in undesired tissue compartments. These problems have been solved by utilizing embryonic stem cell lines (ES), which are derived from pre-implantation mouse embryos. ES cells are totipotent: when introduced into a host blastocyst, or aggregated within a morula-stage embryo, they fully participate to embryogenesis upon introduction into foster mothers and give rise to all tissues normally encountered in the mouse.

Correspondence: A Aguzzi

Received 2 October 1997; revised 16 January 1998; accepted 20 January 1998
While the most popular use of ES cells has been to generate knockout mice by ablating specific segments of the mouse genome, one can also introduce transgenes into mice using ES cells. Animals hosting ES cells are chimeras, consisting only partially of transgenic cells. While fully transgenic animals can be produced by cross-breedings, lethal dominant mutations, which would not allow for development of a transgenic mouse, can be often studied in chimeric transgenic animals (Boulter et al, 1991; Hilberg et al, 1993).

An exciting example use of this technology was recently exemplified by the fusion of AF9 sequences with the mouse Mll gene, which mimics a fusion gene produced by a chromosomal translocation in human acute myeloid leukemias (AML). Chimaeric mice carrying the Mll-AF9 fusion developed AML, despite expression of the transgene in many tissues. Beside providing a useful tool for directing a transgene to a precise chromosomal location, this study formally proves the causal role of the Mll-AF9 sequence translocation in myeloid leukemogenesis (Corral et al, 1996).

A further refinement of the homologous recombination technology is Cre/loxP-mediated site-speci- 
fic recombination. The bacterial Cre protein is capable of mediating sequence-specific recombination of loxP sites, resulting in excision of intervening DNA sequences. The distance between the two loxP sites can be at least as large as $400 \mathrm{~kb}$ (Li et al, 1996), allowing for ablation of extremely large loci. Not only with ES cells exposed to Cre protein in vitro undergo loxP recombination: also transgenic mice expressing the Cre protein in specific tissues will ablate genes included between loxP sites (DiSanto et al, 1995; Gu et al, 1993; Rickert et al, 1997; Zou et al, 1994).

Another problem related to transgene integration concerns the presence of regulatory sequences driving a selectable marker (which, for example, encodes resistance to a certain drug), which may interfere with expression of the transgene that is being studied or with genes adjacent to it. The CREloxP system can eliminate such additional sequences as long as the two loxp sites are in the same orientation. Meanwhile, the Hprt (hypoxanthine phosphoribosyl transferase) locus of the mouse has become a popular site of gene targeting. This locus has been extensively characterized, and allows selection for presence or for absence of enzymatic activity. Moreover, being located on the $\mathrm{X}$ chromosome, it is hermizygous in male animals. In the model of Bronson et al. (Bronson et al, 1996), the mutated Hprt becomes the target for correction of the gene, and the correcting transgene is placed upstream of the locus. This procedure avoids the uncertainties of random integration events: since Hprt is widely expressed in the mouse, ES clones display very reproducible, high expression levels. The 'upstream targeting' characteristic of this model seems to be less prone to promoter occlusion effects that had biased other vector systems.

Several approaches have been developed to achieve transgene inducibility. This can be achieved using expression vectors controlled by derivatives of tetracycline (Kistner et al, 1996; Shockett et al, 1995). Doxycycline is very stable and can be even added to the water supply of the animals, and subtle modifications of the tetresponsive site allow for tet-based repression as well as induction of the transgene. Since the concentration range for induction is different from that needed for repression, one can even express two transgenes in vivo which will be independently controlled by variations in doxycycline concentration (Baron et al, 1997; Bohl and Heard, 1997).

Linkage of the Cre gene to the tet-inducible construct allows recombination to be induced in vivo upon administration of doxycycline (St Onge et al, 1996). Several groups have developed inducible systems utilizing an insect steroid hormone (ecdysone) transduction pathway system (Li et al, 1997a; No et al, 1996). However, their applicability to a wider range of transgenic models remains to be determined.
The expression of many genes is crucially determined by locus control regions, which may be located very far away from the coding sequences. This problem can be addressed by the use of very large vectors, such as PACs (P1 artificial chromosomes), BACs (bacterial artificial chromosomes), YACs (yeast artificial chromosomes) and HACs (human artificial chromosomes). Although both PACs and BACs can clone insert sizes up to $350 \mathrm{~kb}$, transgenesis has so far only been achieved with YACs and, in very few instances, with HACs.

Various methods have been successfully utilized for transfecting YAC DNA into ES cells. Initial attempts exploited PEG-induced fusion between ES cells and YAC-containing yeast spheroblasts and selection markers (such as neomycin phosphotransferase), albeit with moderate efficiency. YAC DNA could also be transfected into ES cells upon complexing with liposomes. This method probably offers the best results in terms of DNA integrity. The most widely utilized method for YAC transduction, however, is pronuclear microinjection. Microinjection of YACs is more difficult than the generation of conventional transgenic mice, because very large molecules can easily break, and calls for the use of agents which protect DNA from shearing. The efficiency of transgenesis with YACs is not always lower than that of conventional fragment microinjection: transgene integration was seen in $10-$ $14 \%$ of embryos microinjected with a $248 \mathrm{~kb}$ human $\beta$-globin YAC (Peterson et al, 1993) and in up to $17 \%$ with a $250 \mathrm{~kb}$ mouse tyrosinase YAC (Schedl et al, 1993).

Additional strategies for creating YAC transgenes include the creation of several lines with a series of overlapping clones, as well as 'binary systems' in which animals containing specific cis-controlling sequences are bred with animals containing specific trans-acting factors (Li et al., 1997b). Some of the best studied models relate to the introduction of the human $\beta$-globin locus into transgenic mice (Peterson, 1993, 1995, 1996). The original $248 \mathrm{~kb}$ YAC contained the five functional globin genes as well as upstream (39 kb) and downstream (82 kb) flanking sequences. The upstream flanking sequences contain the locus control region (LCR). The globin transgene appears to operate very similarly to the human locus: the $\varepsilon$-globin gene is expressed very early during gestation. At this time, a first switch occurs which induces the synthesis of $\gamma$-globin in the yolk sac, which lasts till the second switch, which stimulates $\beta$-globin expression. The latter is maintained in adult life. This technology has allowed to study the hereditary persistence of fetal hemoglobin (HPFH), which is not associated with large deletions of $\delta$ - $\beta$ genes and surroundings. Introduction of a base pair substitution which had been identified in HPFH produced a delayed switch in fetal liver as well as persistent expression of $\gamma$-HB in adult life. Also, $\beta$-globin YAC transgenic mice 
were mated with mice expressing high levels of the GATA-1 transcription factor. The results indicate that the latter is essential not only for the activation but also for proper repression of globin genes.

\section{Models involving dominant oncogenes}

Several transgenic neuro-oncological models have been developed in the past. In the following, we will limit our review to the models developed after 1995: for earlier work the reader is referred to our previous article (Aguzzi et al, 1995). We will particularly emphasize those models which employed technical innovations as well as those which seem to open new horizons in the field of neurooncology.

\section{Pinealoblastomas}

Pinealocytes have been extensively studied because they can originate neuroectodermal tumors, and also for their role in the circadian clock. The promoter of tryptophan hydroxylase (TPH) has been also employed to specifically direct transgene expression to neuroendocrine cells. A transgene encompassing a $6.1 \mathrm{~kb}$ TPH promoter fragment directed expression of lacZ to the raphe nucleus and the pineal gland (Huh et al, 1994; Son et al, 1996). Fusion of the TPH promoter to the SV40 large $\mathrm{T}$ antigen caused the appearance of very aggressive and invasive pineal tumors in transgenic animals causing their death at 12-15 weeks of age (Son et al, 1996).

\section{Neuroblastoma}

Neuroblastoma, the most common extracranial tumor of early childhood, often shows typical genetic lesions, such as deletion of the 1p36.1-2 locus $(\Delta 1 \mathrm{p})$, where a tumor suppressor gene for human neuroblastoma is presumed to reside. Several attampts to identify the latter gene among at least seven different candidates have failed so far (Brodeur 1995; Brodeur et al, 1997). Furthermore, susceptibility to familial neuroblastoma is not linked to 1p36.1-2 (lod scores of $c a-4$ ) (Maris et al, 1996; Rovigatti 1997). The N-myc proto-oncogene seems to play an important role in the ontogenesis of this tumor. Typically, N-myc amplification (NMA) is found in $25-30 \%$ of neuroblastomas, and involves aggressive, higher-stage disease (Brodeur et al, 1984, 1985, 1988a; Shimada et al, 1995). N-myc may therefore be a marker of progression. Alternatively, two distinct types of neuroblastoma may exist, and the more aggressive form is characterized by NMA (Brodeur 1995; Rovigatti 1992; Tsuchida et al., 1996), particularly since patients with lower stage tumors (characterized by the presence of aneuploid karyotypes and absence of NMA and $\Delta 1 \mathrm{p}$ ) never progress to tumors with NMA and $\Delta 1 \mathrm{p}$ (Brodeur et al, 1997). More than $90 \%$ of high stage neuroblastomas display both NMA and $\Delta 1 \mathrm{p}$ (Brodeur et al, 1988b; Fong et al, 1989, 1992).

Although animal models of neuroblastoma have been presented in the past, they did not reflect all peculiarities of the human condition (Aguzzi et al, 1990, 1992). Despite considerable overexpression of $\mathrm{N}-m y c$ in tumors arising in these mice, the characteristic genetic aberrations described in human neuroblastoma, i.e. amplification of N-myc (NMA) and deletions on the short arm of chromosome $1(\Delta 1 \mathrm{p}$, where a tumor suppressor gene for human neuroblastoma is presumed to reside), were not faithfully reproduced in the available models. A recent transgenic model has provided the first formal proof of the tumorigenic potential of N-myc in vivo (Weiss et al, 1997). Here, the promoter of the tyrosine hydroxylase gene was linked to the cDNA of N-myc. The resulting transgenic lines developed neuroblastomas with an incidence of $5-20 \%$ at $3-$ 6 months of age. Frequency of tumorigenesis was increased to $75 \%$ at 10 months by crossing these transgenics with mice hemizygous for either $N f-1$ or $R B 1$, and approached $100 \%$ at 4 months when the $\mathrm{N}-m y c$ transgene was bred to homozygosity. However, also in this mouse model, secondary genetic lesions did not always coincide with those of human neuroblastoma. Significant chromosomal additions were found in regions syntenic with human chromosomes 6 and 17p (while most of the chromosomal gains in human neuroblastoma are on 17q21.3-qter) and losses for regions syntenic with chromosomes 4, 11, 3 and $\mathrm{X}$. Deletions in regions syntenic with human chromosome 1p36.2-3 were conspicuously absent (Weiss et al, 1997). Intriguingly, secondary chromosomal changes were not documented in all mice. This suggests that the identified additional lesions may not always be necessary for tumor progression, and that they may be complemented for by higher by N-myc expression.

\section{Astrocytic tumors}

Mice expressing the SV-40 large T antigen from the regulatory region of the glial fibrillary acidic protein (GFAP) gene (Danks et al, 1995) developed brain tumors at an extremely early age and rapidly progressed to death within 3 weeks after birth. Two animals developed somewhat milder symptoms and progressed to death at about 28-30 days of age: they were defined as 'late' tumors. The tumors were described as composed by atypical cells in the periventricular subependymal zone. SV40 large $\mathrm{T}$ antigen-expressing cells were scat- 
tered throughout the brain: they also appeared atypical and frequently mitotic. An additional abnormality was hyperplasia of the choroid plexus.

T-antigen positive cells were detached in the peripheral nervous system (PNS) in cells identified as non-myelinating Schwann cells. When cell lines were derived from transgenic brains, two distinct cell populations were identified: one contained astrocyte-like cells, while the other cellular population had an epithelial phenotype. With passaging and starting at about passage $8-10$, the latter cells appeared to become the predominant type in culture, did not consistently express GFAP (although some of them could be induced to express this marker by growth arrest), and did not express intermediate filaments in vitro, as detected by immunofluorescence and electron microscopy. It is therefore questionable whether such tumors, and the cell lines derived from them, can be described as astrocytomas. High expression of the transgene was detected in the choroid plexus, and led to hyperplasia (a typical phenotype of T-antigen transgenic mice) (Messing et al, 1985). The latter, rather than hyperproliferation of astrocytes, was probably responsible for death by occlusive hydrocephalus. GFAP expression is not normally detected in choroid plexus of human or mouse brain, although it can occur ectopically in choroid plexus papillomas (Aguzzi et al, 1997).

In summary, the mice discussed above (Danks et $a l, 1995)$ provide an interesting model for neoplastic transformation of astrocytic precursors. However, the life span of the mice is severely limited and this has impeded the establishment of transgenic families. This problem may be related to the oncogene employed (SV40 large T antigen) which seems to induce transformation of cells at an extremely early stage. In addition, the chosen GFAP regulatory fragment (proximal $2.3 \mathrm{~kb}$ flanking sequence at the $5^{\prime}$ of the gene) may provide a pattern of expression not completely superimposable to that of the endogenous GFAP gene.

In an effort to overcome the problems discussed above, we inserted the $\mathrm{v}$-src oncogene inside the first exon of a GFAP minigene which maintains a large portion of upstream regulatory sequences and the intact structure of the gene with 9 exons, 8 introns and the $3^{\prime}$-untranslated region (Mucke et al, 1991). This structure allows for a very precise transgenic recapitulation of the endogenous GFAP expression pattern. Src has been linked to glioma/ astrocytoma carcinogenesis by several lines of evidence, since gliomas were induced by intracerebral injection of RSV in dogs, and previous studies (Aguzzi et al, 1991) showed that src induces neuroectodermal tumors in rats. Src seems to transform astrocytes with a longer latency period than T-antigen, inducing astrocytoma, anaplastic astrocytoma and finally to glioblastoma multiforme.
Two lines expressing an intact src transgene were obtained. We detected transgene expression in lung, heart, thymus, spleen, ovary and kidneys in addition to the brain (as is the case for the endogenous GFAP gene). On the other hand, Northern blotting analysis revealed src expression only in the brain and in testes, as previously described (Holash et al, 1993). Pathological astrogliosis was detected at 2.5-3 weeks of age. Further steps of carcinogenesis such as dysplasia, pre-neoplasia and neoplasia appeared in the following weeks. Animals with large brain tumors occasionally died very suddenly, perhaps due to sudden transtentorial herniation. The majority of the tumors arose in the brain stem and thalamus, where the highest expression of GFAP and transgene, as well as the first signs of dysplasia, were detected. Some tumors with the morphology of schwannomas arose in the PNS (Weissenberger et al, 1997).

Large malignant tumors displayed areas of necrosis associated with perifocal overexpression of vascular endothelial growth factor (VEGF), a potent inducer of angiogenesis expressed in human glioblastomas (Plate et al, 1993). The gene encoding the cognate VEGF receptor $f 1 k-1$ was also highly expressed in the endothelial comportment around necrotic lesions.

Even after 1 year, the total frequency of overt tumors did not exceed $15-20 \%$. While this low incidence is a drawback for therapeutical studies, it provides a realistic model of human astrocytoma progression. The $s r c$ transgene apparently provides only an initiating step of carcinogenesis and additional genetic lesions contribute to neurocarcinogenesis. In an effort to identify such candidate lesions, we are currently intercrossing heterozygous transgenic src mice with $R b^{+/-}$(Saenz Robles et al, 1994) and with p53 ${ }^{+/-}$mice ** (Jacks et al, 1994a,b), since both genes have been implicated in human astrocytoma progression.

p53 deficient mice have been recently exploited to simulate a multistep model for human gliomas (Donehower, 1996, 1977; Harvey et al, 1995). Astocyte cultures from $\mathrm{p} 53^{+/-}$and $\mathrm{p} 53^{-1-}$ transgenes were compared to cultures obtained from wild-type $\mathrm{p}^{2} 3^{++}$mice (Yahanda et al, 1995). Since

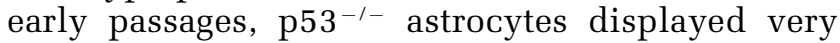
rapid growth. At late passages these cells obtained extremely high saturation densities and gave rise to large, vascularized tumors in nude mice. A similar pattern was observed with cells derived from $\mathrm{p} 53^{+/-}$ animals once they had lost the intact germ line allele. In sharp contrast, cells from p534 $4^{+/+}$animals never underwent such changes, rapidly senesced, and died after 7-10 pasages. The changes in the heterozygous mutants were associated with dramatic karyotypic and ploidy alterations, suggesting that p53 is capable to prevent gross genetic aberrations (Yahanda et al, 1995). 


\section{Olfactory neuroblastomas}

Early olfactory neuroblastoma (ONB, also called esthesioneuroblastoma) models have been covered in our previous review article (Aguzzi et al, 1995). Servenius and colleagues (Servenius et al, 1994) used the olfactory marker protein (OMP) promoter to drive SV40 large T antigen expression: however, transgenic mice developed peripheral tumors resembling neuroblastomas. This finding was surprising since OMP was not known to be expressed in anatomic sites other than olfactory neurons. On the other hand (Carney et al, 1995) showed that OMP is not expressed in human ONB, while a marker of immature olfactory neurons, the Achaete-scute 1 gene HASH-1, is consistently present in human primary and metastatic ONB.

Transgenic mice expressing the early region of Adenovirus E1 from the renin or the angiotensinogen gene promoter developed ONB-like tumors, but also neuroectodermal tumors in the retroperitoneal and pelvic regions (Sugiyama et al, 1995). One further transgenic line developed carcinoid tumors, suggesting that the phenotype of carcinogenesis was highly dependent upon the integration site of the transgene within the host genome (Sagara et al, 1995).

\section{Primitive neuroectodermal tumors (PNET)}

Transgenic mice in which the SV40 T-antigen is driven by the tyrosine hydroxylase promoter (rTHTag mice) developed primitive neuroectodermal tumors (PNETs) essentially undistinguishable from their human counterpart (Fung et al, 1994). The actual mechanism of tumorigenesis is associated with a defect in developmental apoptosis, which prevents the regression of a group of neuroepithelial progenitor stem cells located ventrally to the median eminence (Fung et al, 1995). In normal age-matched controls these progenitor cells spontaneously regress two weeks postnatally, while rTHTag transgenics presented microscopic lesions consisting of packed small blue cells, and later actual PNET. Apoptosis was present but obviously not sufficient to balance the excessive proliferative stimulus. A similar phenomenon occurs in mice expressing SV40 large $\mathrm{T}$ antigen from the insulin promoter, which develop islet cell tumors only if insulin like growth factor II (IGF-II) is produced and counteracts spontaneous apoptosis. Tumor growth is strongly reduced in IGF-II ${ }^{-/-}$mice (Christofori et al, 1995): it may therefore be interesting to determine the effect of IGF-II ablation in rTH-Tag mice.

JCV is the etiologic agent of progressive multifocal leukoencephalopathy (Jochum et al, 1997) and its early region induces demyelination in transgenic mice (Small et al, 1985, 1986a,b. However, these early studies also documented abdominal PNETlike tumors in the founder mice. More recently, heritable PNETs were induced in mice expressing a similar construct (Franks et al, 1996). JCV T antigen probably causes carcinogenesis by binding endogenous p53 and $R b$, as it has been shown in other systems. Finally, the $d b l$ oncogene driven by the neuron specific enolase (NSE) promoter did not induce neuroectodermal tumors in wild type mice but did so in p53 ${ }^{+/-}$mice (Colucci et al, 1995).

\section{Ablation of 'caretaker' and 'gatekeeper' genes}

We have discussed the complex tumor phenotype

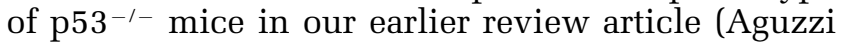
et al, 1995). Many cellular factors, besides p53, have been recognized to feed into the pathways of cell cycle, transformation, apoptosis, and senescence. The terms gatekeepers and caretakers for such regulatory proteins was introduced as a conceptualization of these interactions (Kinzler and Vogelstein, 1997). Gatekeepers are master regulators which interact directly with the different phases of the cell cycle, while caretakers affect the cellular machinery which senses cellular 'wellbeing'. While carcinogenesis seems to be strongly enhanced by loss-of-function of single gatekeeper genes (with an increase of frequency of up to 1000 times), carcinogenesis due to gatekeeper loss of function seems to progress more slowly. p53 is a well-recognized 'gatekeeper' capable of inducing apoptosis if DNA damage occurs. But p53 might be more than a mere 'guardian of genome' (Norimura et al, 1996), and may control several differentiation pathways (Ferreira and Kosik, 1996).

Another gatekeeper prototype, the retinoblastoma tumor suppressor gene $R b$, plays a crucial role during embryogenesis: its ablation leads to embryonic death, while restortion of expression in Rbdeficient embryos allows to prolong the embryonic life up till birth - despite major defects in nervous system, liver and skeletal muscle (Jiang et al, 1997; Zacksenhaus et al, 1996).

Transgenic mice have allowed to study the interaction between $R b$, p53, and other gatekeeper. For example, mice expressing a truncated SV40 large $\mathrm{T}$ antigen which maintains the capability of interacting with $\mathrm{p} R b$ and with $\mathrm{p} 107$, but has lost the capacity of binding p53, do not display the lymphoid abnormalities typically detected in transgenic mice expressing SV40 large $\mathrm{T}$ antigen (McCarthy et al, 1994), yet develop choroid plexus tumors. However, the tumors develop much more slowly than in transgenic mice expressing full length SV40 large $\mathrm{T}$ antigen, with maximum incidence at approximately 8 months instead of the typical 1-2 months (Bowman et al, 1996). This indicates that the p53 binding region of SV40 large $\mathrm{T}$ antigen contributes to tumorigenesis. Attenuation 
of carcinogenesis in the deleted SV40 transgenes probably involves p53-induced apoptosis, which seems to be mediated by the apoptogenic protein Bax. In animals hemizygous for Bax, apoptosis dropped by $50 \%$ and tumor growth was accelerated (Yin et al, 1997). However, if dominant negative mutants of p53 are expressed in these mice, very aggressive tumors develop, indicating that p53 is capable of inhibiting tumor growth, and of exerting a crucial gatekeeping function. Further, p53 is induced in the CNS of $R b$ knockout mice and may stimulate apoptosis. Loss of p53 prevents cell death in $R b$ knockout mice, but does not suffice to restore normal proliferation (Macleod et al, 1996).

The majority of the mouse models in which caretakers have been disrupted or modified have targeted sites other than the nervous system. Disruption of the gene responsible for ataxia teleangiectasia (ATM) reproduced several of the ATM-associated deficits, such as neurologic dysfunction due to degeneration of cerebellar and other neurons, retarded growth, T-cell deficits and extreme sensitivity to $\gamma$-radiation (Barlow et al, 1996). We can therefore expect that ATM-deficient mice will become an important model for oncology.

Other transgenic models have focused on genes involved in apoptosis. Bcl-2 was initially discovered in B-cell lymphoma, and was soon recognized to be an ubiquitous cellular regulator capable of blocking programmed cell death. $B c l-2$ is the prototype of a growing family of proteins involved as positive and negative regulators in the control of cell survival and death (Merry and Korsmeyer, 1997). Bcl-2 is highly expressed during development, but its expression ceases in adult life. However, Bcl-2 may have a physiological role in the maintenance and repair of nervous circuitry (Chen et al, 1997). On the other hand, expression of $B c l-2$, as well as its associated proteins $B c l-X, M c l-1$ and $B a x$, is often dysregulated in brain tumors (Krajewski 1994, 1995, 1997; Weller et al, 1995).

The BRCA1 and BRCA2 genes were identified as susceptibility genes for breast and ovarian cancer (Brugarolas and Jacks, 1997). Several domains of these proteins have been tentatively associated with various functions, but their mode of action is still quite unclear. Mice deficient for BRCA die in utero at approximately E5 - 6 in the case of BRCA 1 and at approximately E7.5-8.5 in the case of BRCA2, probably because of insufficient cellular proliferation. These mice show abnormalities of the neural tube, such as exencephaly and spina bifida, and disorganized development of neuroendocrine cells (Gowen et al, 1996; Hakem et al, 1996, 1997; Liu et al, 1996; Ludwig et al, 1997; Sharan et al, 1997; Suzuki et al., 1997).

Both BRCA-1 and BRCA-2 bind to Rad51, which is the eukaryotic homologue of RecA, one of the most important portein in E. Coli recombination, and co-localize in nuclear structures during mitosis and in meiotic cells. Both BRCA-2 and Rad51 deficient mice show dramatic hypersensitivity to $\gamma$-radiation. Therefore, both BRCA1 and 2 may involved in repair of serious DNA damage, such as double strand breakage. Therefore, these caretaker molecules may exert an important function in DNA repair, and are prime candidate caretakers in tumorigenesis. The paradoxical effects witnessed in BRCA-deficient mutants are probably due to essential functions associated with rapid cellular proliferation during embryogenesis.

\section{Neurofibromatosis}

The Nf-1 gene, whose product is called neurofibromin, was cloned in 1990 as the susceptibility gene for neurofibromatosis 1 (Viskochil et al, 1990; Wallace et al, 1990) and subsequently discovered to encode a member of the GTPase activating proteins (GAP) (Xu et al, 1990). GAPs are capable of terminating ras-mediated signal transduction by triggering the hydrolysis of ras-bound GTP. Nf-1 deficient mice die at midgestation with gross malformations in neural crest-derived structures (Jacks et al, 1994b). Embryonic death is due to major cardiac defects: these abnormalities are likely to be due to impaired migration of neural crest cells, which normally populate the outflow tracts of the heart. Interestingly, in a variant form of $N f-1$, referred to as Watson's syndrome or Noonanfibromatosis syndrome, patients suffer from severe cardiac defects involving pulmonary valvular stenosis (Leao and da Silva, 1995).

Hemizygous $N f-1^{+/-}$mice show a high incidence of tumorigenesis. Most tumors fall into the classical spectrum of $N f-1$ : neurofibrosarcomas, adrenal tumors, and particularly pheochromocytomas, which are exceedingly rare in mice. Myeloid leukemias were also observed: this is consistent with the typical occurrence of myeloid leukemias (particularly juvenile CML) in human $N f 1$. The great majority of tumors show very frequently loss of the non-targeted allele. In addition, adoptive transfer of fetal liver from homozygous $N f-^{-1-}$ embryos induces an aggressive form of myeloid leukemia in the recipients, which appears to be due to hypersensitivity to granulocyte/macrophage colony stimulating factor (GM-CSF) (Largaespada et al, 1996). The latter is apparently due to the activation of RAS signal transduction pathway (STP) (Bollag et al, 1996), suggesting that neurofibromin may be a negative regulator of GM-CSF through RAS-STP.

$N f-1$ knockout mice have also been used to study the role of neurofibromin in the hyperproliferation of Schwann cells characteristic of $N f-1$ lesions (Kim et al, 1995). The changes induced in Schwann cells resemble the effects of v-ras. Ras-GAP deficient mice show a phenotype similar to that of $N f-1^{-\prime-}$ mutants: endothelial cells seem to be particularly affected and 
incapable of organizing a vascular network. Furthermore, double mutants mice show an exacerbated phenotype, as would be expected of genes acting in parallel pathways of signal transduction (Henkemeyer et al, 1995). In Gap/Nf-1 double mutants the neural tube hyperproliferates and invades the head mesenchyme (Henkemeyer et al, 1995).

The tax gene of HTLV is also capable of inducing multiple neurofibromas in transgenic animals resembling those of human $N f-1$ (Hinrichs et al, 1987). Further studies have showed that the tax gene is indeed a negative trans-regulator of the neurofibromin gene (Feigenbaum et al, 1996). This mechanism may modify $N f-1$ gene expression and contribute to tumorigenesis.

A wealth of information about the signal transduction pathways to which $N f-1$ participates is coming from studies with transgenic flies. In $N f$-1deficient flies, the most obvious phenotype was a reduction in the sizes of larvae, pupae and adults (Guo et al, 1997; The et al, 1997). Heterozygous loss of the Gap1 gene did not exacerbate the phenotype, but homozygous loss of both $N f-1$ and Gap1 resulted in lethality during larval development. However, manipulation of other effectors of the same pathway, such as Ras1 or SOS or Rafor did not dramatically change the phenotype, thus suggesting that $N f-1$ acts through a pathway slightly different from Ras and which may involve kinase A (Guo et al, 1997; The et al, 1997).

\section{Neuroectodermal tumors and hedgehog signalling}

The patched and sonic hedgehog (shh) proteins participate to a signal transduction pathway that includes gli, the family of wnt genes, that of transforming growth factors $\beta$ (TGF- $\beta$ ), DPC4, APC, $\beta$-catenin, GSK3B, the nuclear regulators $\mathrm{p} 15$ and $\mathrm{p} 16$, the cyclin-dependent kinase inhibitors p21 and p27, E2F as well p53 and RB. Hedgehog belongs to a family of regulatory genes which were initially dissected by in Drosophila Melanogaster. An increasing number of such genes has been identified from vertebrate species such as mouse and man. The mouse sonic hedgehog (shh) gene product can function as a morphogen in the patterning of the developing limb. Further, it can induce somitic cells to acquire a sclerotomal fate, and it induces patterning of the ventral neural tube. Floor plate induction occurs through surface-bound $\mathrm{SHH}$ molecules in direct physical contact with the neural plate, whereas the other two functions require a longrange patterning signal. Accordingly, mice deficient for shh die at birth with malformations of the frontal brain (Chiang et al, 1996) similar to the human condition known as holoprosencephaly (HPE). The latter occurs in 1/16000 of live birth and in 1/250 aborted fetuses, and was mapped to at least four loci (21q22.3, 2p21, 7q36 and 18p11.3). Recently, one of these loci was mapped to the shh locus (Belloni et al, 1996). The alterations detected in this gene consist of chromosomal translocations affecting its regulatory elements, or of nonsense and missense mutations (Belloni et al, 1996; Roessler et al, 1996).

Patched (ptc), a 12-transmembrane protein receptor, is the receptor for $\mathrm{HH}$ (Marigo et al, 1996; Stone et al, 1996). Another receptor called smoothened or smo participates to the signal transduction pathway. Ptc gene expression is normally inhibited and becomes activated only in the presence of $\mathrm{HH}$ induction. PTC represses this signal by binding and inactivating SMO. In the presence of $\mathrm{HH}$, PTC releases SMO, which induces target genes including $w g$ (wingless) and $d p p$ (decapentaplegic). The latter gene, $d p p$, shares homology with the TGF- $\beta$ gene family, and interacts with TGF- $\beta$ receptors. Signal transduction of the $p t c / d p p$ pathway involves a gene which had been identified as a maternal effect enhancer of Drosophila $d p p$ embryonic patterning mutants: this gene was therefore called 'mothers against $d p p$ ' or mad. There seems to be a very high specificity in the interaction of the TGF family receptors with their ligand and in the interaction of MAD related proteins with their receptor.

Expression of mutant genes belonging to the three hedgehog pathways (wnt, hedgehog, and $d p p$ ) has helped characterizing the effects of p53 deficiency on mammary carcinogenesis induced by wnt family members (Donehower et al, 1995; Frank et al, 1997; Gunther et al, 1994; Lagna et al, 1996; Lee et al, 1995). Ectopic expression of Wnt-1 could be induced by the Hoxb-4 region A enhancer (Dickinson et al, 1994), and caused a great increase in mitotic rate and expansion of the cells of the ventricular region. Interestingly, wnt-1 acted solely as a mitogenic stimulus in the CNS, rather than a patterning signal in this model, since developmental abnormalities were not evident.

A further gene belonging to the $d p p / \operatorname{tgf}-\beta$ pathway was isolated by positional cloning upon the observation that extensive deletions of chromosome 18 are present in human pancreatic carcinomas. This led to the final identification of DPC4, which is now believed to be involved in more than $50 \%$ of pancreatic carcinomas. DPC4 is highly homologous to $\mathrm{mad}$, and displays frequent mutations in its carboxy terminus which may induce transcriptional activtion (Chu, 1997; Frank et al, 1997; Lagna et al, 1996; Moskaluk and Kern, 1996).

Transgenic mouse models have provided considerable insights into the hedgehog pathways. The group of M Scott, who initially discovered mutations of the patched gene in nevoid basal cell carcinoma syndrome, linked the shh gene to a keratin promoter in order to obtain overexpression in the skin (Johnson et al, 1996; Oro et al, 1997). Transgenic mice showed alterations similar to those seen in BCNS (such as polydactily and spina bifida (McMahon and Chuang, 1996)) as well as alterations 
involving skin structure and epidermal cell proliferation (Fan et al, 1997; Oro et al, 1997). These findings prompted a search for shh mutations in human cancers, but only somatic mutations were detected in approximately $10 \%$ and $30 \%$ of the total and desmoplastic cases, respectively (Pietsch et al, 1997; Raffel et al, 1997; Vorechovsky et al, 1997; Xie et al, 1997).

A further model is based upon alteration of patched, whose mutations are linked to BCNS in humans. The neurooncological relevance of this gene derives from the occurrence of aggressive medullobalstomas in a small percentage of BCNS patients. Mice with a homozygous ablation of ptc died early in utero E9.0-E10.5) with several congenital abnormalities, confirming the essential role of ptc as an inducer of dorsalization (Goodrich, 1997). Most interestingly, a high incidence of medulloblastomas was documented in the cerebellum of hemizygous mice. Predictably, gli was highly expressed in these tumors. The incidence of medulloblastoma increased with age $(8.3 \%$ at 5 weeks and 9-10 weeks, up to $30 \%$ in animals at 12-25 weeks), similarly to what is observed in other models. This suggests that additional changes, such as loss of the second allele of ptc and possibly secondary genetic lesions, are required for formation of medulloblastomas.

\section{Choroid plexus tumors}

It has been long known that transgenic expression of the SV40 viral enhancer and large-T antigen efficiently induces tumors of the choroid plexus (Palmiter et al, 1985). More recently, mutant of the IgH intronic enhancer ENHiH coupled to the SV40 large- $\mathrm{T}$ antigen was shown to induce choroid plexus tumors (Enjoji et al, 1995). This enhancer contains motifs which direct expression to B-cells, whose removal (Enjoji, 1994) renders the construct permissible for expression in brain cells. In a cell line established from such choroid plexus tumors (which expresses typical markers such as stransthyretin and alpha2-macroglobulin), an etslike transcriptional regulator was shown to bind to the transgenic enhancer and to be probably important for directing expression to the choroid plexus (Enjoji, 1994). The choroid plexus tumor model proved extremely useful also for studying the interactions of SV40 large T antigen with p53, RB, and apoptogenic proteins such as bax, as discussed in detail in a former section of this review [Saenz Robles, 1994\#1331; (Yin et al, 1997).

\section{Multiple endocrine neoplasia}

The hallmark of multiple endocrine neoplasia type 2 (MEN 2) syndrome is the development of medullary thyroid carcinomas (MTC), which are responsible for the high lethality of this syndrome (DeLellis et al, 1986). MEN 2 is one of the very few hereditary cancer syndromes with a dominant pattern of inheritance. The gene responsible is the RET transmembrane receptor (Myers et al, 1995), and mutations responsible for MEN 2 appear to activate the RET kinase (Eng et al, 1994, 1995; Mulligan et al, 1994a,b). A different type of mutation is responsible for a certain percentage of familial Hirschsprung's disease: these are inactivating, loss-of-function mutations (Pasini et al, 1995). Accordingly, in RET deficient mice there is not development of enteric nervous system, kidney agenesis, and lack of intestinal autonomic ganglia (Schuchardt et al, 1994, 1995). Several studies have shown that RET is the receptor for the glial cell derived neurotropic factor (GDNF) (Durbec et al, 1996; Treanor et al, 1996; Trupp et al, 1996). Three additional animal studies confirmed these results by showing tht mice lacking the GDNF gene display both kidney agenesis and abnormalities of the enteric nervous system (Moore et al, 1996; Pichel et al, 1996; Sanchez et al, 1996).

While MEN2B seems to be due to a unique mutation in the active site of the tyrosine kinase domain (Carlson et al, 1994; Donis Keller, 1995; Pandit et al, 1996), in MEN2A mutations affect one of five cysteine residues clustered in the extracellular domain of the receptor (Chi et al, 1994; Donis Keller et al, 1993; Mulligan et al, 1994a,b). When a ret construct with a typical MEN2A mutation was linked to the calcitonin gene related peptide promoter in order to target its expresion to thyroid C cells, hyperplasia of thyroid C cells occurred and was followed by multifocal and bilateral medullary thyroid carcinomas in three independent transgenic lines of mice (Michiels et al, 1997). These intriguing results confirm the role of RET as a dominant oncogene responsible for thyroid tumorigenesis.

\section{Pituitary tumors}

Due to its interest for molecular endocrinology, mammalian reproduction, and development, carcinogenesis in the pituitary gland has been addressed by a wealth of transgenic models over the past few years. In several instances, tumor growth or carcinogenesis were dependent on the hormonal status. A transgene encoding the polyoma early region promoter linked to a cDNA encoding polyome large $\mathrm{T}$ antigen induced pituitary tumors (Helseth et al, 1995) which produced adrenocorticotropic hormone (ACTH). At 13-16 months of age, such animals develop pituitary macroadenomas with elevated ACTH plasma levels. Transplantation of such tumors into nude mice led to a considerable increase in ACTH levels and the weight of the 
Table 1 Transgenic models of neurocarcinogenesis

\begin{tabular}{|c|c|c|}
\hline Tumor type & Transgene or ablated gene & Phenotype \\
\hline Pineoblastoma & $\begin{array}{c}\text { Tph-LacZ } \\
\text { Tph-T-ag SV40 }\end{array}$ & $\begin{array}{l}\text { Expression in pineal gland (Huh et al., 1994) } \\
\text { Aggressive pineal tumors (Son et al., 1996) }\end{array}$ \\
\hline Neuroblastoma & Tyrosine hydroxylase N-myc & Neuroblastomas: (Weiss et al., 1997) \\
\hline Astrocytic tumors & $\begin{array}{l}\text { GFAP (2.3 kb)-T-ag SV40 } \\
\text { GFAP (whole gene) v-src }\end{array}$ & $\begin{array}{c}\text { Choroid plexus hyperpl. +undifferentiated tumors } \\
\text { (Danks et al., 1995) } \\
\text { Astrocytomas (Weissenberger et al., 1997) }\end{array}$ \\
\hline Olfactory neuroblastoma (ONB) & $\begin{array}{l}\text { Omp T-ag sv40 } \\
\text { Renin/angiotensin E1 adeno-12 }\end{array}$ & $\begin{array}{l}\text { Neuroblastomas (ectopic) (Servenius et al., 1994) } \\
\text { Olfactory neuroectodermal tumors (Sugiyama et al., 1995) }\end{array}$ \\
\hline $\begin{array}{l}\text { Primitive neuroectodermal } \\
\text { tumors (PNET) }\end{array}$ & Tyrosine hydroxylase T-ag sv40 & PNET (Fung et al., 1994; Fung and Trojanowski, 1995) \\
\hline & $\begin{array}{l}\text { JCV-T-ag } \\
\text { Neuron specific enolase }-D b l \\
\text { oncogene }\end{array}$ & $\begin{array}{c}\text { PNET (Franks et al., 1996) } \\
\text { PNET (only in p53 }{ }^{+1-} \text { ) (Colucci et al., 1995) }\end{array}$ \\
\hline Gatekeeper genes ablation & $\begin{array}{l}\text { p53 } \\
\text { T-ag SV40 mutant } \\
\text { Atm }^{-1-} \\
\text { Bcl- }^{-1-} \\
\text { P107 }\end{array}$ & $\begin{array}{c}\text { Tumor predisposition, occasional embryo lethality } \\
\text { (Norimura et al., 1996) } \\
\text { Slowly growing tumors P53 bind./bax apoptosis } \\
\text { (Bowman et al., 1996; McCarthy et al., 1994) [Yin, 1997\#1313] } \\
\text { Extremely sensitive to -rays (Barlow et al., 1996) } \\
\text { Axonal repair impeded (Cen et al., 1997) } \\
\text { Embryo lethality (e14.5) Affected: cns and liver } \\
\text { (Jiang et al., 1997; Zacksenhaus et al., 1996) }\end{array}$ \\
\hline Caretaker genes ablation & $\begin{array}{l}\text { Brca1 }^{-1-} \\
\text { Brca2 }\end{array}$ & $\begin{array}{l}\text { Embryonic lethality (e5-6) (Hakem et al., 1996) } \\
\text { Embryonic lethality (e7.5-8.5) Sharan, 1997\#1910) }\end{array}$ \\
\hline Neurofibromatosis (Nf-1) & 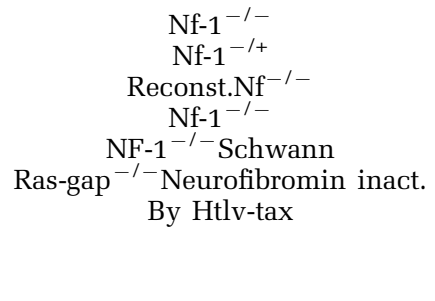 & $\begin{array}{c}\text { Lethality heart+nervous system (Brannan et al., 1994) } \\
\text { Phaechromocytomas and myeloid leukemias (Jacks et al., 1994b) } \\
\text { Myeloprolif. (JCML) (Largaespada et al., 1996) } \\
\text { Hypersens to GM-CSF (Bollag et al., 1996) } \\
\text { Similar to v-ras (Kim et al., 1995) } \\
\text { Die E10.5: cns+endoth (Henkemeyer et al., 1995) } \\
\text { Localized neurofibromas: Additional mechanisms } \\
\text { (Feigenbaum et al., 1996; Hinrichs et al., 1987) } \\
\text { Size reduct.-PK-A involv. }\end{array}$ \\
\hline Hedgehog Signaling & $\begin{array}{l}\text { Hoxb-4a enhancer-Wnt } 1 / 2 \\
\text { and p53-I- } \\
\text { Keratin-14-Shh }\end{array}$ & $\begin{array}{c}\text { Cooperation in carcinog. between wnt and p53. } \\
\text { Mitogenicity of wnt } \\
\text { Basal cell nevus syndrome (Fan et al., 1997; Oro et al., 1997) } \\
\text { (Dickinson et al., 1994; Donohower et al., 1995; } \\
\text { Gunther et al., 1994; Lee et al., 1995) } \\
\text { Lethal e9-e10.5 } \\
\text { Large size, syndactily, cerebellar medulloblastoma } \\
\text { (30\% at } 5-6 \text { months) (Goodrich, 1997) }\end{array}$ \\
\hline $\begin{array}{l}\text { Multiple Endocrine Neoplasia } \\
\text { (MEN) }\end{array}$ & $\begin{array}{l}\text { Ret }^{-/-} \\
\text {GDNF }^{-/-} \\
\text {CGRP promoter }(2 \mathrm{~kb}) \\
\text { Ret }^{\text {cys634 } \rightarrow \text { arg }}\end{array}$ & $\begin{array}{c}\text { Renal agenesis/Hirschsprung's disease } \\
\text { (Schuchardt et al., 1994, 1995, 1996) } \\
\text { Comparable to ret }{ }^{-\prime-} \text { : both show same phenotype } \\
\text { Bilateral C cell hyperplasia multifocal MTC (3 weeks-2 years) } \\
\text { (Michiels et al., 1997) }\end{array}$ \\
\hline Choroid plexus tumors & SV40/IgH enhancer T-ag SV40 & $\begin{array}{l}\text { Tumors: ets-like trascription factor activation } \\
\text { (Enjoji, 1994, 1995) (Saenz Robles et al., 1994; } \\
\text { Symonds et al., 1994; Yin et al., 1997) }\end{array}$ \\
\hline Pituitary Tumors & $\begin{array}{c}\text { PyLT } \\
\text { LH/FSH promoters-Tag SV40 }\end{array}$ & $\begin{array}{l}\text { Micro and macroadenomas Cushing's syndrome } \\
\text { (Helseth et al., 1992, 1995; Holm et al., 1993) } \\
\text { Pituitary tumors/immortal cell lines } \\
\text { (Alarid et al., 1996; Turgeon et al., 1996) }\end{array}$ \\
\hline
\end{tabular}


animals. Therefore, this transgene model provides a realistic model of human Cushing's disease (Helseth et al, 1992; Holm et al, 1993).

In a very interesting model developed by the group of P Mellon, the SV40 large T antigen was expressed under the regulatory control of various promoters, in order to test whether different target cells may be immortalized in specific stages of differentiation (Alarid et al, 1996). Cells from an immature gonadotropic cell line are less differentiated and express the alpha subunit as well as the gonadotropin releasing hormone receptor, while more differentiated cell lines were obtained by oncogenesis with SV40 large T linked to promoters of LH/FSH (Alarid et al, 1996). A L $\beta$ T2 gonadotropic cell line, also obtained from a transgenic mouse containing the SV40 large T antigen linked to the rat LH $\beta$-subunit regulatory region, was shown to respond to steroid hormone regulation and to pulses of gonadotropin releasing hormone (Turgeon et al, 1996).

\section{Ependymomas}

As discussed in a previous review article (Aguzzi et al, 1995), it has been amply demonstrated in the past that transgenes encompassing the early region of the SV40 virus display a tropism for ependymal cells and choroid plexus, and SV40 large T antigen is capable of inducing both ependymomas and choroid plexus tumors when driven by its homologous promoter. Carcinogenesis of these target cells could be induced also by the oncogenes of the human papillomavirus type 16, E6 and E7. Therefore, some type of specificity for viral sequence expression or viral promoters seems to be present in ependymal cells. Intriguingly, also the major immediate early promoter of human cytomegalovirus

\section{References}

Aguzzi A, Brandner S, Isenmann S, Steinbach JP, Sure U (1995). Transgenic and gene disruption techniques in the study of neurocarcinogenesis. Glia 15: $348-364$.

Aguzzi A, Ellmeier W, Weith A (1992). Dominant and recessive molecular changes in neuroblastomas. BrainPathol 2: $195-208$.

Aguzzi A, Kleihues P, Heckl K, Wiestler OD (1991). Cell type-specific tumor induction in neural transplants by retrovirus-mediated oncogene transfer. Oncogene 6: $113-118$.

Aguzzi A, Wagner EF, Williams RL, Courtneidge SA (1990). Sympathetic hyperplasia and neuroblastomas in transgenic mice expressing polyoma middle $\mathrm{T}$ antigen. New-Biol 2: 533-543.

Aguzzi A, Weber T, Paulus W (1997). Choroid plexus tumors. In: Pathology and Genetics of Brain Tumors. $\mathrm{P}$ Kleihues and W Cavenee, eds. (Lyon: Int. Soc. of Neuropathology).
(HCMV), when introduced into transgenic mice, (Fritschy et al, 1996), targeted expression of a reporter gene to ependymal cells and choroid plexus epithelia (among other, predominantly neural crest-derived targets). Since HCMV can cause severe and devastating congenital disorders in human embryos, as well as ependymitis in immunocompromised adults, such studies are of potentially great interest in understanding whether pathology correlates with specific gene expression. These data are consistent with the presence of specific, probably transacting, regulatory mechanisms which permit expression of viral genes in these cells.

\section{Concluding remarks}

The increasing number of transgenic animals utilized for studies on neurocarcinogenesis is documented by the plethora of new articles published only two years after our initial review. Certainly, the most recent transgenic systems aim at increased specificity and reproducibility of the natural situations which they attempt to model. The new tools for specific targeting of genomic loci have now made such goals attainable.

The wealth of information now available on the biochemical pathways of signal transduction, allows for more meaningful experiments. Moreover, transgenic studies have become a natural complement to reverse genetics, in which susceptibility genes are being detected by linkage analysis and positional cloning. On the basis of the discoveries of the last few years, we predict that transgenic mice will not only be instrumental for understanding the function of newly discovered oncogenes and tumor suppressor genes, but also for uncovering unexpected functions of genes long known.

Alarid ET, Windle JJ, Whyte DB, Mellon PL (1996). Immortalization of pituitary cells at discrete stages of development by directed oncogenesis in transgenic mice. Development 122: 3319-3329.

Barlow C, Hirotsune S, Paylor R, Liyanage M, Eckhaus M, Collins F, Shiloh Y, Crawley JN, Ried T, Tagle D, Wynshaw Boris A (1996). Atm-deficient mice: a paradigm of ataxia telangiectasia. Cell 86: 159-171.

Baron U, Gossen M, Bujard H (1997). Tetracycline controlled transcription in eukaryotes: novel transactivators with graded transactivation potential. Nucleic Acids Research 25: 2723-2729.

Belloni E, Muenke M, Roessler E, Traverso G, Siegel Bartelt J, Frumkin A, Mitchell HF, Donis Keller H, Helms C, Hing AV, Heng HH, Koop B, Martindale D, Rommens JM, Tsui LC, Scherer SW (1996). Identification of Sonic hedgehog as a candidate gene responsible for holoprosencephaly. Nat-Genet 14: 353-356. 
Bohl D, Heard JM (1997). Modulation of erythropoietin delivery from engineered muscles in mice. Human Gene Therapy 8: 195-204.

Bollag G, Clapp DW, Shih S, Adler F, Zhang YY, Thompson P, Lange BJ, Freedman MH, McCormick F, Jacks T, Shannon K. (1996). Loss of NF1 results in activation of the Ras signaling pathway and leads to aberrant growth in haematopoietic cells. Nat-Genet 12: $144-148$

Boulter CA, Aguzzi A, Williams RL, Wagner EF, Evans MJ, Beddington R. (1991). Expression of v-src induces aberrant development and twinning in chimaeric mice. Development 111: 357-366.

Bowman T, Symonds H, Gu L, Yin C, Oren M, Van Dyke $\mathrm{T}$ (1996). Tissue-specific inactivation of p53 tumor suppression in the mouse. Genes-Dev 10: 826-835.

Brannan CI, Perkins AS, Vogel KS, Ratner N, Nordlund ML, Reid SW, Buchberg AM, Jenkins NA, Parada LF, Copeland NG (1994). Targeted disruption of the neurofibromatosis type-1 gene leads to developmental abnormalities in heart and various neural crestderived tissues. Genes-Dev 8: 1019-1029.

Brodeur GM (1995). Molecular basis for heterogeneity in human neuroblastomas. Eur J Cancer 4: 505-510.

Brodeur GM, Fong CT, Morita M, Griffith R, Hayes FA, Seeger RC (1988a). Molecular analysis and clinical significance of $\mathrm{N}$-myc amplification and chromosome 1p monosomy in human neuroblastomas. Prog Clin Biol Res 271: 3-15.

Brodeur GM, Maris JM, Yamashiro DJ, Hogarty MD, White PS (1997). Biology and genetics of human neuroblastomas. Journal of Pediatric Hematology Oncology 19: 93-101.

Brodeur GM, Seeger RC, Barrett A, Berthold F, Castleberry RP, D’Angio G, De Bernardi B, Evans AE, Favrot M, Freeman AI et al (1988b). International criteria for diagnosis, staging, and response to treatment in patients with neuroblastoma (see comments). J-ClinOncol 6: $1874-1881$.

Brodeur GM, Seeger RC, Schwab M, Varmus HE, Bishop JM (1984). Amplifiction of N-myc in untreated human neuroblastomas correlates with advanced disease stage. Science 224, 1121-1124.

Brodeur GM, Seeger RC, Schwab M, Varmus HE, Bishop JM (1985). Amplification of N-myc sequences in primary human neuroblastomas: correlation with advanced disease stage. Prog Clin Biol Res 175: $105-113$.

Bronson SK, Plaehn EG, Kluckman KD, Hagaman JR, Maeda N, Smithies O (1996). Single-copy transgenic mice with chosen-site integration [see comments]. Proc Natl Acad Sci USA 93: 9067-9072.

Brugarolas J, Jacks T (1997). Double indemnity: p53, brca and cancer. Nature Medicine 3: 721-722.

Carlson KM, Dou S, Chi D, Scavarda N, Toshima K, Jackson CE, Wells SA Jr, Goodfellow PJ, Donis Keller $H$ (1994). Single missense mutation in the tyrosine kinase catalytic domain of the RET protooncogene is associated with multiple endocrine neoplasia type 2B. Proc Natl Acad Sci USA 91: 1579-1583.

Carney ME, O’Reilly RC, Sholevar B, Buikova OI, Lowry LD, Keane WM, Margolis FL, Rothstein JL (1995). Expression of the human Achaete-scute 1 gene in olfactory neuroblastoma (esthesioneuroblastoma). J Neurooncol 26: $35-43$.
Chen DF, Schneider GE, Martinou JC, Tonegawa S (1997). Bcl 2 promotes regeneration of severed axons in mammalian cns. Nature 385: 434-439.

Chi DD, Toshima K, Donis Keller H, Wells SA Jr (1994). Predictive testing for multiple endocrine neoplasia type 2A (MEN 2A) based on the detection of mutations in the RET protooncogene. Surgery 116: 124-132; discussion 132-133.

Chiang C, Litingtung Y, Lee E, Young KE, Corden JL, Wesphal H, Beachy PA (1996). Cyclopia and defective axial patterning in mice lacking Sonic hedgehog gene function. Nature 383: 407-413.

Christofoi G, Naik P, Hanahan D (1995) Deregulation of both imprinted and expressed alleles of the insulinlike growth factor 2 gene during beta-cell tumorigenesis. Nat Genet 10: 196-201.

Chu TM (1997). Molecular diagnosis of pancreas carcinoma. Journal of Clinical Laboratory Analysis 11: $225-231$

Colucci D’Amato GL, Santelli G, A DA, Chiappetta G, Mineo A, Manzo G, Vecchio G, de Franciscis V (1995). Dbl expression driven by the neuron specific enolase promoter induces tumor formation in transgenic mice with a p53( $\left(^{+/-}\right)$genetic background. Biochem Biophys Res Commun 216: $762-770$.

Corral J, Lavenir I, Impey H, Warren AJ, Forster A, Larson TA, Bell S, McKenzie AN, King G, Rabbitts TH (1996). An Mll-AF9 fusion gene made by homologous recombination causes acute leukemia in chimeric mice: a method to create fusion oncogenes. Cell 85: $853-861$.

Danks RA, Orian JM, Gonzales MF, Tan SS, Alexander B, Mikoshiba K, Kaye AH (1995). Transformation of astrocytes in transgenic mice expressing SV40 T antigen under the transcriptional control of the glial fibrillary acidic protein promoter. Cancer Res 55: $4302-4310$

DeLellis RA, Dayal Y, Tischler AS, Lee AK, Wolfe HJ (1986). Multiple endocrine neoplasia (MEN) syndromes: cellular origins and interrelationships. Int Rev Exp Pathol 28: 163-215.

Dickinson ME, Krumlauf R, McMahon AP (1994). Evidence for a mitogenic effect of Wnt-1 in the developing mammalian central nervous system. Development 120: $1453-1471$.

DiSanto JP, Muller W, Guy Grand D, Fisher A, Rajewsky $\mathrm{K}$ (1995). Lymphoid development in mice with a targeted deletion of the interleukin 2 receptor gamma chain. Proc Natl Acad Sci USA 92: 377-381.

Donehower LA (1997). Genetic instability in animal tumorigenesis models. Cancer Surveys 29: 329-352.

Donehower LA (1996). The p53 deficient mouse: a model for basic and applied cancer studies. Seminars in Cancer Biology 7: 269-278.

Donehower LA, Godley LA, Aldaz CM, Pyle R, Shi YP, Pinkel D, Gray J, Bradley A, Medina D, Varmus HE (1995). Deficiency of p53 accelerates mammary tumorigenesis in Wnt-1 transgenic mice and promotes chromosomal instability. Genes Dev 9: 882-895.

Donis Keller H (1995). The RET proto-oncogene and cancer. J Intern Med 238: 319-325. 
Donis Keller H, Dou S, Chi D, Carlson KM, Toshima K, Lairmore TC, Howe JR, Moley JF, Goodfellow P, Wells SA Jr (1993). Mutations in the RET proto-oncogene are associated with MEN 2A and FMTC. Hum Mol Genet 2: 851-856.

Durbec P, Marcos Gutierrez CV, Kilkenny C, Grigoriou M, Wartiowaara K, Suvanto P, Smith D, Ponder B, Costantini F, Saarma M et al. (1996). GDNF signalling through the Ret receptor tyrosine kinase (see comments). Nature 381: 789-793.

Eng C, Smith DP, Mulligan LM, Healey CS, Zvelebil MJ, Stonehouse TJ, Ponder MA, Jackson CE, Waterfield MD, Ponder BA (1995). A novel point mutation in the tyrosine kinase domain of the RET proto-oncogene in sporadic medullary thyroid carcinoma and in a family with FMTC. Oncogene 10: 509-513.

Eng C, Smith DP, Mulligan LM, Nagai MA, Healey CS, Ponder MA, Gardner E, Scheumann GF, Jackson CE, Tunnacliffe A et al. (1994). Point mutation within the tyrosine kinase domain of the RET proto-oncogene in multiple endocrine neoplasia type $2 \mathrm{~B}$ and related sporadic tumours (published erratum appears in Hum Mol Genet Apr 3(4): 686). Hum Mol Genet 3: $237-$ 241.

Enjoji M (1994). Human HE2 (microB) and microA motifs show the same function as whole IgH intronic enhancer in transgenic mice. Mol Cell Biochem 137: $33-37$.

Enjoji M, Iwaki T, Nawata $H$, Watanabe $\mathrm{T}$ (1995). IgH intronic enhancer element HE2 (mu B) functions as a cis-activator in choroid plexus cells at the cellular level as well as in transgenic mice. $J$ Neurochem 64: 961-966.

Fan HR, Oro AE, Scott MP, Khavari PA (1997). Induction of basal cell carcinoma features in transgenic human skin expressing sonic hedgehog. Nature Medicine 3: $788-792$.

Feigenbaum L, Fujita K, Collins FS, Jay G (1996). Repression of the NF1 gene by Tax may explain the development of neurofibromas in human T-lymphotropic virus type 1 transgenic mice. J Virol 70: $3280-$ 3285.

Ferreira A, Kosik KS (1996). Accelerated neuronal differentiation induced by p53 suppression. J Cell SCi 109: 1509-1516.

Fong CT, Dracopoli NC, White PS, Merrill PT, Griffith RC, Housman DE, Brodeur GM (1989). Loss of heterozygosity for the short arm of chromosome 1 in human neuroblastomas: correlation with N-myc amplification. Proc Natl Acad Sci USA 86: 3753-3757.

Fong CT, White PS, Peterson K, Sapienza C, Cavenee WK, Kern SE, Vogelstein B, Cantor AB, Look AT, Brodeur GM (1992). Loss of heterozygosity for chromosomes 1 or 14 defines subsets of advanced neuroblastomas. Cancer Res 52: 1780-1785.

Frank CJ, McClatchey KD, Devaney KO, Carey TE (1997). Evidence that loss of chromosome 18q is associated with tumor progression. Cancer Research 57: 824827.

Franks RR, Rencic A, Gordon J, Zoltick PW, Curtis M, Knobler RL, Khalili K (1996). Formation of undifferentiated mesenteric tumors in transgenic mice expressing human neurotropic polymavirus early protein. Oncogene 12: 2573-2578.
Fritschy JM, Brandner S, Aguzzi A, Koedood M, Luscher B, Mitchell PJ (1996). Brain cell type specificity and gliosis-induced activation of the human cytomegalovirus immediate-early promoter in transgenic mice. $J$ Neurosci 16: 2275-2282.

Fung KM, Chikaraishi DM, Suri C, Theuring F, Messing A, Albert DM, Lee VM, Trojanowski JQ (1994). Molecular phenotype of simian virus 40 large $\mathrm{T}$ antigen-induced primitive neuroectodermal tumors in four different lines of transgenic mice. Lab Invest 70: $114-124$.

Fung KM, Lee VM, Trojanowski JQ (1995). Dynamics of cell proliferation and cell death during the emergence of primitive neuroectodermal tumors of the immature central nervous system in transgenic mice. Am J Pathol 146: $1376-1387$.

Fung KM, Trojanowski JQ (1995). Animal models of medulloblastomas and related primitive neuroectodermal tumors. A review. J Neuropathol Exp Neurol 54: $285-296$.

Goodrich LV, Milenkovitch L, Higgins KM, Scott MP (1997). Altered Neural Fates and Medulloblastoma in Mouse patched Mutants. Science 277: 1109-1113.

Gowen LC, Johnson BL, Latour AM, Sulik KK, Koler BH (1996). Brca1 deficiency results in early embryonic lethality characterized by neuroepithelial abnormalities. Nat Genet 12: 191-194.

Gu H, Zou YR, Rajewsky K (1993) Independent control of immunoglobulin switch recombination at individual switch regions evidenced through Cre-loxPmediated gene targeting. Cell 73: 1155-1164.

Gunther T, Struwe M, Aguzzi A, Schughart K (1994). Open brain, a new mouse mutant with several neural tube defects, shows altered gene expression patterns in the developing spinal cord. Development 120: $3119-3130$.

Guo HF, The I, Hannan F, Bernards A, Zhong Y (1997). Requirement of Drosophila NF1 for activation of adenylyl cyclase by PACAP38-like neuropeptides. Science 276: 795-798.

Hakem R, de la Pompa JL, Sirard C, Mo R, Woo M, Hakem A, Wakeham A, Potter J, Reitmair A, Billia F, Firpo E, Hui CC, Roberts J, Rossant J, Mak TW (1996). The tumor suppressor gene Brca1 is required for embryonic cellular proliferation in the mouse. Cell 85: $1009-1023$.

Hakem R, Delapompa JL, Eli A, Potter J, Mak TW (1997). Partial rescue of brca1(56) early embryonic lethality by p53 or p21 null mutation. Nature Genetics 16: $298-302$.

Hanahan D (1989). Transgenic mice as probes into complex systems. Science (AAAS) 246: 1265-1275.

Harvey M, Vogel H, Morris D, Bradley A, Bernstein A, Donehower LA (1995). A mutant p53 transgene accelerates tumour development in heterozygous but not nullizygous p53-deficient mice. Nat Genet 9: $305-311$.

Helseth A, Haug E, Nesland JM, Siegal GP, Fodstad O, Bautch VL (1995). Endocrine and metabolic characteristics of polyoma large $\mathrm{T}$ transgenic mice that develop ACTH-producing pituitary tumors. $J$ Neurosurg 82: 879-885. 
Helseth A, Siegal GP, Haug E, Bautch VL (1992). Transgenic mice that develop pituitary tumors. A model for Cushing's disease. Am J Pathol 140: 10711080.

Henkemeyer M, Rossi DJ, Holmyard DP, Puri MC, Mbamalu G, Harpal K, Shih TS, Jacks T, Pawson T (1995). Vascular system defects and neuronal apoptosis in mice lacking ras GTPase-activating protein. Nature 377: 695-701.

Hilberg F, Aguzzi A, Howells N, Wagner EF (1993). c-jun is essential for normal mouse development and hepatogenesis [published erratum appears in Nature 366: 368]. Nature 365: 179-181.

Hinrichs SH, Nerenberg M, Reynolds RK, Khoury G, Jay $G$ (1987). A transgenic mouse model for human neurofibromatosis. Science 237: 1340-1343.

Holash JA, Harik SI, Perry G, Stewart PA (1993). Barrier properties of testis microvessels. Proc Natl Acad Sci USA 90: 11069-11073.

Holm R, Helseth A, Nesland JM, Bautch VL (1993). ACTH-producing pituitary tumors in transgenic mice. An ultrastructural and immunoelectron microscopic study. J Submicrosc Cytol Pathol 25: 29-36.

Huh SO, Park DH, Cho JY, Joh TH, Son JH (1994). A $6.1 \mathrm{~kb} 5^{\prime}$ upstream region of the mouse tryptophan hydroxylase gene directs expression of E. coli lacZ to major serotonergic brain regions and pineal gland in transgenic mice. Brain Res Mol Brain Res 24: 145152.

Jacks T, Remington L, Williams BO, Schmitt EM, Halachmi S, Bronson RT, Weinberg RA (1994a). Tumor spectrum analysis in p53-mutant mice. Curr Biol 4: 1-7.

Jacks T, Shih TS, Schmitt EM, Bronson RT, Bernards A, Weinberg RA (1994b). Tumour predisposition in mice heterozygous for a targeted mutation in Nf1. Nat Genet 7: $353-361$.

Jiang Z, Zacksenhaus E, Gallie BL, Phillips RA (1997). The retinoblastoma gene family is differentially expressed during embryogenesis. Oncogene 14: 1789-1797.

Jochum W, Weber T, Frye S, Hunsmann G, Lüke G, Aguzzi A (1997). Detection of JC virus by anti-VP1 immunohistochemistry in brains with progressive multifocal leukoencephalopathy. Acta Neuropathol 94: $226-231$.

Johnson RL, Rothman AL, Xie J, Goodrich LV, Bare JW, Bonifas JM, Quinn AG, Myers RM, Cox DR, Epstein EH Jr, Scott MP. (1996). Human homolog of patched, a candidate gene for the basal cell nevus syndrome. Science 272: $1668-1671$.

Kim HA, Rosenbaum T, Marchionni MA, Ratner N, DeClue JE (1995). Schwann cells from neurofibromin deficient mice exhibit activation of p21ras, inhibition of cell proliferation and morphological changes. Oncogene 11: $325-335$.

Kinzler KW, Vogelstein B (1997). Cancer-susceptibility genes. Gatekeepers and caretakers (news; comment). Nature 386: 761, 763.

Kistner A, Gossen M, Zimmermann F, Jerecis J, Ullmer C, Lubbert H, Bujard H (1996). Doxycycline-mediated quantitative and tissue-specific control of gene expression in transgenic mice. Proc Natl Acad Sci USA 93: $10933-10938$.
Krajewski S, Krajewska M, Ehrmann J, Sikorska M, Lach B, Chatten J, Reed JC (1997). Immunohistochemical analysis of bcl 2, bcl x, mcl 1, and bax in tumors of central and peripheral nervous system origin. American Journal of Pathology 150: 805-814.

Krajewski S, Krajewska M, Shabaik A, Wang HG, Irie S, Fong L, Reed JC (1994). Immunohistochemical analysis of in vivo patterns of Bcl-X expression. Cancer Res 54: $5501-5507$.

Krajewski S, Mai JK, Krajewska M, Sikorska M, Mossakowski MJ, Reed JC (1995) Upregulation of bax protein levels in neurons following cerebral ischemia. J Neurosci 15: 6364-6376.

Lagna G, Hata A, Hemmati Brivanlou A, Massague J (1996). Partnership between DPC4 and SMAD proteins in TGF-beta signalling pathways. Nature 383: 832836.

Largaespada DA, Brannan CI, Jenkins NA, Copeland NG (1996). Nf1 deficiency causes Ras-mediated granulocyte/macrophage colony stimulating factor hypersensitivity and chronic myeloid leukaemia. Nat Genet 12: $137-143$.

Leao M, da Silva ML (1995) Evidence of central nervous system involvement in Watson syndrome. Pediatr Neurol 12: 252-254.

Lee FS, Lane TF, Kuo A, Shackleford GM, Leder P (1995). Insertional mutagenesis identifies a member of the Wnt gene family as a candidate oncogene in the mammary epithelium of int-2/Fgf-3 transgenic mice. Proc Natl Acad Sci USA 92: 2268-2272.

Li C, Schwabe JWR, Banayo E, Evans RM (1997a). Coexpression of nuclear receptor partners increases their solubility and biological activities. Proceedings of The National Academy of Sciences of The United States of America 94: 2278-2283.

Li Q, Clegg C, Peterson K, Shaw S, Raich N, Stamatoyannopoulos G (1997b). Binary transgenic mouse model for studying the trans control of globin gene switching: evidence that GATA-1 is an in vivo repressor of human epsilon gene expression. Proc Natl Acad Sci USA 94: 2444-2448.

Li ZW, Stark G, Gotz J, Rulicke T, Muller U, Weissmann C (1996). Generation of mice with a $200 \mathrm{~kb}$ amyloid precursor protein gene deletion by Cre recombinasemediated site-specific recombination in embryonic stem cells. Proc Natl Acad Sci USA 93: 6158-6162.

Liu CY, Flesken Nikitin A, Li S, Zeng Y, Lee WH (1996). Inactivation of the mouse Brca1 gene leads to failure in the morphogenesis of the egg cylinder in early postimplantation development. Genes Dev 10: 18351843.

Ludwig T, Chapman DL, Papaioannou VE, Efstratiadis A (1997). Targeted mutations of breast cancer susceptibility gene homologs in mice: lethal phenotypes of brca1, brca2, brca1/brca2, brca1/p53, and brca2/p53 nullizygous embryos. Genes and Development. 11: $1226-1241$

Macleod KF, Hu Y, Jacks T (1996). Loss of Rb activates both p53-dependent and independent cell death pathways in the developing mouse nervous system. EMBO J 15: 6178-6188. 
Magrio V, Davey RA, Zuo Y, Cunningham JM, Tabin CJ (1996). Biochemical evidence that patched is the Hedgehog receptor (see comments). Nature 384: $176-179$.

Maris JM, Kyemba SM, Rebbeck TR, White PS, Sulman EP, Jensen SJ, Allen C, Biegel JA, Yanofsky RA, Feldman GL, Brodeur GM (1996). Familial predisposition to neuroblastoma does not map to chromosome band 1p36. Cancer Res 56: 3421-3425.

McCarthy SA, Symonds HS, Van Dyke T (1994). Regulation of apoptosis in transgenic mice by simian virus $40 \mathrm{~T}$ antigen-mediated inactivation of p53. Proc Natl Acad Sci USA 91: 3979-3983.

McMahon AP, Chuang PT (1996). Hedgehogs in the clinic. Nat Med 2: 1308-1310.

Merry DE, Korsmeyer SJ (1997). Bcl-2 gene family in the nervous system. Annu Rev Neurosci 20: 245-267.

Messing A, Chen HY, Palmiter RD, Brinster RL (1985). Peripheral neuropathies, hepatocellular carcinomas and islet cell adenomas in transgenic mice. Nature 316: $461-463$.

Michiels FM, Chappuis S, Caillou B, Pasini A, Talbot M, Monier R, Lenoir GM, Feunteun J, Billaud M (1997). Development of medullary thyroid carcinoma in transgenic mice expressing the ret protooncogene altered by a multiple endocrine neoplasia type 2a mutation. Proceedings of The National Academy of Sciences of the United States of America. 94: 33303335.

Moore MW, Klein RD, Farinas I, Sauer H, Armanini M, Phillips H, Reichardt LF, Ryan AM, Carver Moore K, Rosenthal A (1996) Renal and neuronal abnormalities in mice lacking GDNF. Nature 382: 76-79.

Moskaluk CA, Kern SE (1996). Cancer gets Mad: DPC4 and other TGFbeta pathway genes in human cancer. Biochim Biophys Acta 1288: M31-33.

Mucke L, Oldstone MB, Morris JC, Nerenberg MI (1991). Rapid activation of astrocyte-specific expression of GFAP-lacZ transgene by focal injury. New Biol 3: $465-474$.

Mulligan LM, Eng C, Healey CS, Clayton D, Kwok JB, Gardner E, ponder MA, Frilling A, Jackson CE, Lehnert H, et al. (1994a). Specific mutations of the RET proto-oncogene are related to disease phentype in MEN 2A and FMTC. Nat Genet 6: 70-74.

Mulligan LM, Eng C, Healey CS, Ponder MA, Feldman GL, Li P, Jackson CE, Ponder BA (1994b). A de novo mutation of the RET proto-oncogene in a patient with MEN 2A. Hum Mol Genet 3: 1007-1008.

Myers SM, Eng C, Ponder BA, Mulligan LM (1995). Characterization of RET proto-oncogene $3^{\prime}$ splicing variants and polyadenylation sites: a novel C-terminus for RET. Oncogene 11: 2039-2045.

No D, Yao TP, Evans RM (1996). Ecdysone-inducible gene expression in mammalian cells and transgenic mice. Proc Natl Acad Sci USA 93: 3346-3351.

Norimura T, Nomoto S, Katsuki M, Gondo Y, Kondo S (1996). p53-dependent apoptosis suppresses radiationinduced teratogenesis [see comments]. Nat Med 2: $577-580$.

Oro AE, Higgins KM, Hu ZL, Bonifas JM, Epstein EH, Scott MP (1997). Basal cell carcinomas in mice overexpressing sonic hedgehog. Science 276: $817-$ 821.
Palmiter RD, Chen HY, Messing A, Brinster RL (1985). SV40 enhancer and large $\mathrm{T}$ antigen are instrumental in development of choroid plexus tumours in trnsgenic mice. Nature 316: $457-460$.

Pandit SD, Donis Keller H, Iwamoto T, Tomich JM, Pike LJ (1996). The multiple endocrine neoplasia type $2 \mathrm{~B}$ point mutation alters long-term regulation and enhances the transforming capacity of the epidermal growth factor receptor. J Biol Chem 271: 5850-5858.

Pasini B, Borrello MG, Greco A, Bongarzone I, Luo Y, Mondellini P, Alberti L, Miranda C, Arighi E, Bocciardi $\mathrm{R}$ et al. (1995). Loss of function effect of RET mutations causing Hirschsprung disease. Nat Genet 10: $35-40$.

Peterson KR, Clegg CH, Huxley C, Josephson BM, Haugen HS, Furukawa T, Stamatoyannopoulos G (1993). Transgenic mice containing a $248 \mathrm{~kb}$ yeast artificial chromosome carrying the human beta-globin locus display proper developmental control of human globin genes. Proc Natl Acad Sci USA 90: 75937597.

Peterson KR, Clegg CH, Navas PA, Norton EJ, Kimbrough TG, Stamatoyannopoulos G (1996). Effect of deletion of $5^{\prime} \mathrm{HS} 3$ or $5^{\prime} \mathrm{HS} 2$ of the human beta-globin locus control region on the developmental regulation of globin gene expression in berta-globin locus yeast artificial chromosome transgenic mice. Proc Natl Acad Sci USA 93: 6605-6609.

Peterson KR, Li QL, Clegg CH, Furukawa T, Navas PA, Norton EJ, Kimbrough TG, Stamatoyannopoulos G (1995). Use of yeast artificial chromosomes (YACs) in studies of mammalian development: production of beta-globin locus YAC mice carrying human globin developmental mutants. Proc Natl Acad Sci USA 92: $5655-5659$.

Pichel JG, Shen L, Sheng HZ, Granholm AC, Drago J, Grinberg A, Lee EJ, Huang SP, Saarma M, Hoffer BJ, Sariola H, Westphal $H$ (1996). Defects in enteric innervation and kidney development in mice lacking GDNF. Nature 382: 73-76.

Pietsch T, Waha A, Koch A, Kraus J, Albrecht S, Tonn J, Sorensen N, Berthold F, Henk B, Schmandt N, Wolf HK, von Deimling A, Wainwright B, Chenevix Trench G, Wiestler OD, Wicking C (1997). Medulloblastomas of the desmoplastic variant carry mutations of the human homologue of Drosophila patched. Cancer Res 57: $2085-2088$.

Plate KH, Breier G, Millauer B, Ullrich A, Risau W (1993). Up-regulation of vascular endothelial growth factor and its cognate receptors in a rat glioma model of tumor angiogenesis. Cancer Res 53: 5822-5827.

Raffel C, Jenkins RB, Frederick L, Hebrink D, Alderete B, Fults DW, James CD (1997). Sporadic medullobalstomas contain PTCH mutations. Cancer Res 57: 842845.

Rickert RC, Roes J, Rajewsky K (1997). B lymphocytespecific, Cre-mediated mutagenesis in mice. Nucleic Acids Res 25: 1317-1318.

Roessler E, Belloni E, Gaudenz K, Jay P, Berta P, Scherer SW, Tsui LC, Muenke M (1996). Mutations in the human Sonic Hedgehog gene cause holoprosencephaly. Nat Genet 14: $357-360$. 
Rovigatti U, Martucciello G, Jasonni V (1997). Genetic alterations in neuroblastoma appear as a genetic make-up more than a single locus mutation. Heriditary Cancer 2 Edited by J-M Haefliger, H-J Muller, RJ Scott, and W Weber, 11-36.

Rovigatti U (1992). Isolation and initial characterization of a new virus: Micro-Foci inducing virus or MFV. CR Acad Sci III 315: 195-202.

Saenz Robles MT, Symonds H, Chen J, Van Dyke T (1994). Induction versus progression of brain tumor development: differential functions for the pRB- and p53-targeting domains of simian virus $40 \mathrm{~T}$ antigen. Mol Cell Biol 14: 2686-2698.

Sagara M, Sugiyama F, Horiguchi H, Kamma H, Ogata T, Yagami K, Murakami K, Fukamizu A (1995). Activation of the nuclear oncogenes N-myc and c-jun in carcinoid (correction of cartinoid) tumors of transgenic mice carrying the human adenovirus type 12 E1 region gene. DNA Cell Biol 14: 95-101.

Sanchez MP, Silos Santiago I, Frisen J, He B, Lira SA, Barbacid M (1996). Renal agenesis and the absence of enteric neurons in mice lacking GDNF. Nature 382: $70-73$

Schedl A, Larin Z, Montoliu L, Thies E, Kelsey G, Lehrach H, Schutz G (1993). A method for the generation of YAC transgenic mice by pronuclear microinjection. Nucleic Acids Res 21: 4783-4787.

Schuchardt A, D’Agati V, Larsson Blomberg L, Costantini F, Pachnis V (1994). Defects in the kidney and enteric nervous system of mice lacking the tyrosine kinase receptor Ret (see comments). Nature 367: 380-383.

Schuchardt A, D'Agati V, Larsson Blomberg L, Costantini F, Pachnis V (1995). RET-deficient mice: an animal model for Hirschsprung's disease and renal agenesis. $J$ Intern Med 238: $327-332$.

Schuchardt A, D’Agati V, Pachnis V, Costantini F (1996). Renal agenesis and hypodysplasia in ret-k- mutant mice result from defects in uretreric bud development. Development 122: 1919-1929.

Servenius B, Vernachio J, Price J, Andersson LC, Peterson PA (1994). Metastasizing neuroblastomas in mice transgenic for simian virus 40 large $\mathrm{T}$ (SV40T) under the olfactory marker protein gene promoter. Cancer Res 54: 5198-5205.

Sharan SK, Morimatsu M, Albrecht U, Lim DS, Regel E, Dinh C, Sands A, Eichele G, Hasty P, Bradley A (1997). Embryonic lethality and radiation hypersensitivity mediated by rad51 in mice lacking brca2 . Nature 386: $804-810$.

Shimada H, Stram DO, Chatten J, Joshi VV, Hachitanda Y, Brodeur GM, Lukens JN, Matthay KK, Seeger RC (1995). Identification of subsets of neuroblastomas by combined histopathologic and N-myc analysis. J Natl Cancer Inst 87: 1470-1476.

Shockett P, Difilippantonio M, Hellman N, Schatz DG (1995). A modified tetracycline-regulated system provides autoregulatory, inducible gene expression in cultured cells and transgenic mice. Proc Natl Acad Sci USA 92: 6522-6526.

Small JA, Blair DG, Showalter SD, Scangos GA (1985). Analysis of a transgenic mouse containing simian virus 40 and v-myc sequences. Mol Cell Biol 5: 642648 .
Small JA, Khoury G, Jay G, Howley PM, Scangos GA (1986a). Early regions of JC virus and BK virus induce distinct and tissue-specific tumors in transgenic mice. Proc Natl Acad Sci USA 83: 8288-8292.

Small JA, Scangos GA, Cork L, Jay G, Khoury G (1986b). The early region of human papovavirus JC induces dysmyelination in transgenic mice. Cell 46: 13-18.

Son JH, Chung JH, Huh SO, Park DH, Peng C, Rosenblum MG, Chung YI, Joh TH (1996). Immortalization of neuroendocrine pinealocytes from transgenic mice by targeted tumorigenesis using the tryptophan hydroxylase promoter. Brain Res Mol Brain Res 37: 32-40.

St Onge L, Furth PA, Gruss P (1996). Temporal control of the Cre recombinase in transgenic mice by a tetracycline responsive promoter. Nucleic Acids Res $243875-3877$

Stone DM, Hynes M, Armanini M, Swanson TA, Gu Q, Johnson RL, Scott MP, Pennica D, Goddard A, Phillips H, Noll M, Hooper JE, de Sauvage F, Rosenthal A (1996). The tumour-suppressor gene patched encodes a candidate receptor for Sonic hedgehog (see comments). Nature 384: 129-134.

Sugiyama F, Sagara M, Matsuda Y, Horiguchi H, Kamma H, Ogata T, Hatae T, Yagami K, Murakami K, Fukamizu A (1995). Heritable formation of neuroectodermal tumor in transgenic mice carrying the combined E1 region gene of adenovirus type 12 with the deregulated human renin promoter. $J$ Cell Biochem 57: 691-700.

Suzuki A, Delapompa JL, Hakem R, Elia A, Yoshida R, Mo R, Nishina H, Chuang T, Wakeham A, Itie A, Koo W, Billia P, Ho A, Fukumoto M, Hui CC, Mak TW (1997). Brca2 is required for embryonic cellular proliferation in the mouse. Genes and Development 11: $1242-1252$.

Symonds H, Krall L, Remington L, Saenz Robles M, Lowe S, Jacks T, Van Dyke T (1994). p53-dependent apoptosis suppresses tumor growth and progression in vivo. Cell 78: $703-711$.

The I, Hannigan GE, Cowley GS, Reginald S, Zhong Y, Gusella JF, Hariharan IK, Bernards A (1997). Rescue of a drosophila nf1 mutant phenotype by protein kinase a. Science 276: $791-794$.

Treanor JJ, Goodman L, de Sauvage F, Stone DM, Poulsen KT, Beck CD, Gray C, Armanini MP, Pollock RA, Hefti F, Phillips HS, Goddard A, Moore MW, Buj Bello A, Davies AM, Asai N, Takahashi M, Vandlen R, Henderson CE, Rosenthal A (1996). Characterization of a multicomponent receptor for GDNF (see comments). Nature 382: 80-83.

Trupp M, Arenas E, Fainzilber M, Nilsson AS, Sieber BA, Grigoriou M, Kilkenny C, Salazar Grueso E, Pachnis V, Arumae U et al. (1996) Functional receptor for GDNF encoded by the c-ret proto-oncogene (see comments). Nature 381: 785-788.

Tsuchida Y, Hemmi H, Inoue A, Obana K, Yang HW, Hayashi Y, Kanda N, Shimatake H (1996). Genetic clinical markers of human neuroblastoma with special reference to N-myc oncogene: amplified or not amplified?-An overview. Tumour Biol 17: 65-74. 
Turgeon JL, Kimura Y, Waring DW, Mellon PL (1996). Steroid and pulsatile gonadotropin-releasing hormone $(\mathrm{GnRH})$ regulation of luteinizing hormone and $\mathrm{GnRH}$ receptor in a novel gonadotrope cell line. Mol Endocrinol 10: 439-450.

Viskochil D, Buchberg AM, Xu G, Cawthon RM, Stevens J, Wolff RK, Culver M, Carey JC, Copeland NG, Jenkins NA et al. (1990). Deletions and a translocation interrupt a cloned gene at the neurofibromatosis type 1 locus. Cell 62: 187-192.

Vorechovsky I, Tingby O, Hartman M, Stromberg B, Nister M, Collins VP, Toftgard R (1997). Somatic mutations in the human homologue of drosophila patched in primitive neuroectodermal tumours. Oncogene. 15: $361-366$.

Wallace MR, Marchuk DA, Andersen LB, Letcher R, Odeh HM, Saulino AM, Fountain JW, Brereton A, Nicholson J, Mitchell AL et al. (1990). Type 1 neurofibromatosis gene: identification of a large transcript disrupted in three NF1 patients [published erratum appears in Science 250:1749]. Science 249: $181-186$.

Weiss WA, Aldape K, Mohapatra G, Feuerstein BG, Bishop JM (1997). Targeted expression of mycn causes neuroblastoma in transgenic mice. Embo Journal 16: 2985-2995.

Weissenberger J, Steinbach JP, Malin G, Spada S, Rulicke T, Aguzzi A (1997). Development and malignant progression of astrocytomas in GFAP-v-src transgenic mice. Oncogene 14: 2005-2013.
Weller M, Malipiero U, Aguzzi A, Reed JC, Fontana A (1995). Protooncogene bcl-2 gene transfer abrogates Fas/APO-1 antibody-mediated apoptosis of human malignant glioma cells and confers resistance to chemotherapeutic drugs and therapeutic irradiation. J Clin Invest 95: 2633-2643.

Xie J, Johnson RL, Zhang X, Bare JW, Waldman FM, Cogen PH, Menon AG, Warren RS, Chen LC, Scott MP, Epstein EH Jr (1997). Mutations of the PATCHED gene in several types of sporadic extracutaneous tumors. Cancer Res 57: 2369-2372.

Xu GF, O’Connell P, Viskochil D, Cawthorn R, Robertson M, Culver M, Dunn D, Stevens J, Gesteland R, White $\mathrm{R}$ et al. (1990). The neurofibromatosis type 1 gene encodes a protein related to GAP. Cell 62: 599-608.

Yahanda AM, Bruner JM, Donehower LA, Morrison RS (1995). Astrocytes derived from p53-deficient mice provide a multistep in vitro model for development of malignant gliomas. Mol Cell Biol 15: 4249-4259.

Yin C, Knudson CM, Korsmeyer SJ, Van Dyke T (1997). Bax suppresses tumorigenesis and stimulates apoptosis in vivo. Nature 385: 637-640.

Zacksenhaus E, Jiang Z, Chung D, Marth JD, Phillips RA, Gaille BL (1996). pRb controls proliferation, differentiation, and death of skeletal muscle cells and other lineages during embryogenesis. Genes Dev 10: $3051-$ 3064.

Zou YR, Muller W, Gu H, Rajewsku K (1994). Cre-loxPmediated gene replacement: a mouse strain producing humanized antibodies. Curr Biol 4: 1099-1103. 